\title{
Effect of Boron Carbide on wear resistance of graphite containing Al7029 Based Hybrid Composites and its Dry Sliding Wear Characterization Through Experimental, Response Surface Method and ANOVA
}

\author{
Madhu K S, Venkatesh C V, Sharath B N, Karthik S \\ Malnad College of Engineering, Affiliated to VTU, Belagavi, Karnataka, India \\ Corresponding author: Madhu K S, (mks@mcehassan.ac.in)
}

\begin{abstract}
Composites are often chosen for tribological applications due to its tailored material properties. The development of hybrid metal matrix composites and the study of their wear behavior has been a prominent focus of materials science research. Present paper deals with fabrication of Al-7029/B $\mathrm{C} / \mathrm{Gr}$ hybrid composite using stir casting. Particle distribution and material phase are identified by SEM and XRD. Hardness of the composite increased to $101 \mathrm{BHN}$ while base alloy with $63 \mathrm{BHN}$. Pin-on-disc Tribometer used to carry wear test and the experimentation conducted by considering three input wear control parameters: 15-35 N (load), 1.5-3.5 m/s (speed) and 200-600 m (distance). Addition of $6 \% \mathrm{~B} 4 \mathrm{C} / 3 \% \mathrm{Gr}$, wear rate of hybrid composites reduced. ANOVA confirmed that load as the most influencing parameter on wear rate. RSM results correlates with mean effect plots of ANOVA and experiments and found that the results are in good compliance. SEM graphs of worn surface confirms that more wear occurred with increased load.
\end{abstract}

Keywords: A17029, Boron carbide, Graphite, Response surface method

\section{Introduction:}

Composites have an extensive choice of applications in the aerospace and automotive sectors due to its tailored properties [1]. In the recent year's efforts have been made to develop a composite with hard reinforcements like $\mathrm{B}_{4} \mathrm{C}$, $\mathrm{SiC}, \mathrm{Al}_{2} \mathrm{O}_{3}$ etc. Boron carbide $\left(\mathrm{B}_{4} \mathrm{C}\right)$ improves tensile strength, impact strength, toughness, and interface bonding with the Aluminium matrix. Due to its self-lubricating properties, Graphite decreases the composite wear rate [2]. Aluminium Metal Matrix Composites (AMMCs) supplemented with particles have the potential to improve qualities obtained through traditional methods [3]. Powder metallurgy has been reported to produce fracture damage to reinforcement and is costly. Squeeze casting causes substantial reinforcing damage and is moderately expensive. Stir casting generated less reinforcing damage, more versatile, cost-effective and not limited in shape or size [4]. Any humidity in ceramic particles is evaporated out during the first phase of heating, thus reducing porosity. Stir casting to combine matrix and reinforcement by melting is experimentally very convenient process. The observation of microstructures suggests that stirring action produces smaller grain than unstirred grain [5]. For high wear resistance with enhanced hardness and oxidation resistance, composites consisting of hard ceramics are desired. The results show that the friction coefficient along with wear rates of AMMCs are lower [6]. By using high vacuum casting at room temperature, dry sliding behavior of $\mathrm{Al} 7075$ reinforced with RHA (rice husk) and $\mathrm{B}_{4} \mathrm{C}$ (boron carbide) were carried by varying weight percentage of reinforcement. Hybrid composite wear resistance improved at $8 \%$ RHA and $8 \% \mathrm{~B}_{4} \mathrm{C}$, which in turn lowered composite wear rate as sliding velocity and applied load increased. [7]. Al-Cu-Mg alloy with $\mathrm{B}_{4} \mathrm{C}, \mathrm{Al}_{2} \mathrm{O}_{3}$ and $\mathrm{Gr}$ as reinforcement were studied by experimental and statistical method using pin-on-disc and Artificial Neural Network (ANN). Wear resistance of Hybrid Metal Matrix Composites (HMMCs) found to be increased by $30 \%$ at $\mathrm{Al} 2219 / 5 \% . \mathrm{B}_{4} \mathrm{C} / 2 \% \mathrm{Gr}$. The most influencing factor on wear rate was applied load and sliding speed compared to sliding distance. The obtained wear rate results with experimental results showed the minimum error by $1 \%$ [8]. The tribological effects of Aluminium alloys 7075 reinforced with $\mathrm{Al}_{2} \mathrm{O}_{3}$ were investigated using a liquid casting process. The composites wear resistance found enhanced by addition of $6 \% \mathrm{Al}_{2} \mathrm{O}_{3}$ and results of Taguchi and response surface were correlated [9]. With increase in $\mathrm{B}_{4} \mathrm{C}$ wt. $\%$ Al-Mg/B $\mathrm{B}_{4} \mathrm{C} / \mathrm{Ti}$ composites offer higher wear resistance due to increased hardness. But increase in $\mathrm{Ti}$ wt. \% reduced the composite wear resistance. By reducing loads, adhesion and delamination found predominant wear behavior of $\mathrm{Al}-\mathrm{Mg} / \mathrm{B}_{4} \mathrm{C} / \mathrm{Ti}$ composites. At higher loads melting and thermal softening influenced wear behavior of $\mathrm{Al}-\mathrm{Mg} / \mathrm{B}_{4} \mathrm{C} / \mathrm{Ti}$ composites [10]. The optimal degree of $\mathrm{B}_{4} \mathrm{C}$ reinforcement to enhance the aluminium alloys wear resistance was investigated. To create aluminium hybrid 
Table 1. Al7029 alloy Chemical composition (weight fraction \%) [1]

\begin{tabular}{lllllllll}
\hline Si & Fe & Cu & Mn & Mg & Zn & Ti & V & Al \\
\hline $\mathbf{0 . 1 0}$ & 0.12 & $0.5-0.9$ & 0.03 & $1.3-2.0$ & $4.2-5.2$ & 0.05 & 0.05 & Remaining
\end{tabular}

composites, $\mathrm{B}_{4} \mathrm{C}$ reinforcement and a constant amount of 3 $\% \mathrm{Gr}$ were combined with an aluminium alloy. According to the results of SEM micrographs, $\mathrm{B}_{4} \mathrm{C}$ reinforcement of up to $9 \%$ was shown to be favourable since it boosted the wear resistance of the aluminium alloy. A consistent amount of graphite added acts as lubricant [11].

Suresha. S et.al., have found friction coefficient of $\mathrm{Al} /$ $\mathrm{SiC} / \mathrm{Gr}$ HMMCs was investigated. It was found, load has the greatest influence on HMMCs friction coefficient and sliding speed with medium effect after load. HMMCs friction coefficient grew as the load and sliding distance increased [12]. Imran. $M$ et.al., have studied wear behavior of $\mathrm{Al} 7075 /$ Bagasse ash/Gr hybrid composites. Wear rate improved as the amount of ceramic phase weight rose, indicating that wear behavior of hybrid composites including graphite was superior [13]. Baradeswaran et.al., found the effect of $\mathrm{B}_{4} \mathrm{C}$ reinforced with Al-7075 alloy. Composite hardness value rose linearly with volume percentage of $\mathrm{B}_{4} \mathrm{C}$ was raised. In addition, the wear effect was determined to be the least in the composite with $10 \%$ $\mathrm{B}_{4} \mathrm{C}$ [14]. Balaji. S et.al., produced Al7050 alloy with $12 \mathrm{wt} \%$ of zirconium dioxide $(\mathrm{ZrO} 2)$ composites by conventional stir casting method. Pin-on-disc apparatus used to perform wear test by experimental study and Response surface methodology (RSM) used to correlate experimental results.

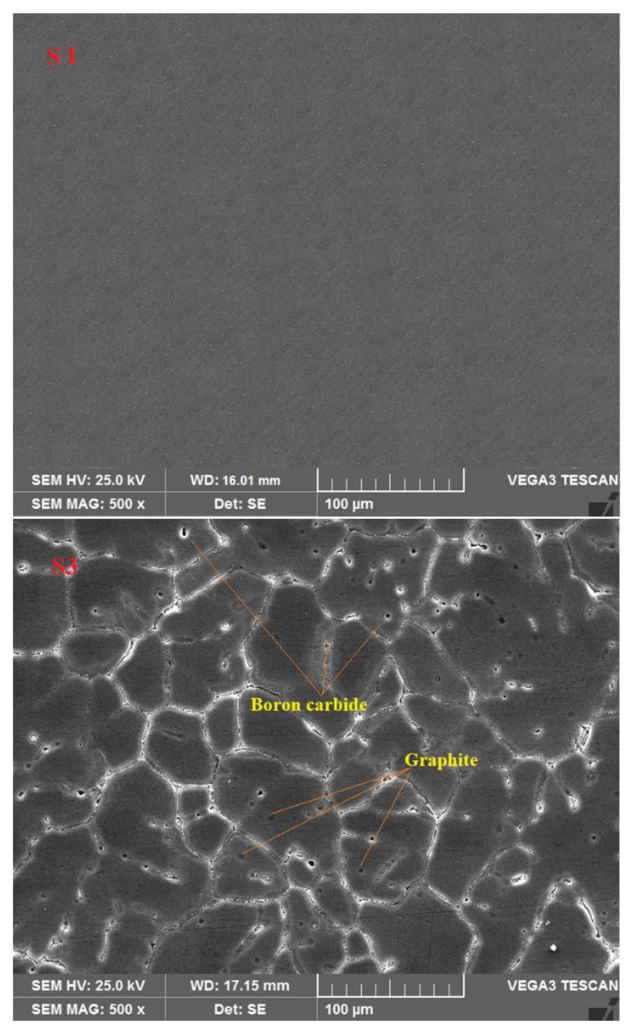

Fig. 1: SEM micrographs of cast samples
Table 2. Material composition in weight percentage

\begin{tabular}{lccc}
\hline Sample & $\begin{array}{c}\text { Al7029 } \\
\text { wt. \% }\end{array}$ & $\begin{array}{c}\text { Boron Carbide } \\
\text { wt. \% }\end{array}$ & $\begin{array}{c}\text { Graphite } \\
\text { wt. } \%\end{array}$ \\
\hline S1 & 100 & 0 & 0 \\
S2 & 95 & 2 & 3 \\
S3 & 93 & 4 & 3 \\
S4 & 91 & 6 & 3 \\
\hline
\end{tabular}

The optimum surface parameter was found at $10.0784 \mathrm{~N}$, $1.8647 \mathrm{~m} / \mathrm{s}$ and $829.788 \mathrm{~m}$. Analysis of Variance performed confirmed that load has major significant factor, which influencing the MMCs wear rate [15]. Kumar. R et.al., performed wear test on Al7075 alloy and Al7075/7 wt. \% of $\mathrm{SiC} / 3$ wt.\% Gr using pin-on disc. Scanning electron microscope was used to examine the tested samples to identify the wear debris, mixing of reinforcement and worn surfaces. Statistical method RSM, used found that load as most significant parameter compared to speed and sliding distance for a composite [16]. Rajesh. S et.al., used Taguchi and RSM to select the best combination of wear parameters influencing the coefficient of friction and specific wear rate in red mud-based Aluminium composites fabricated using powder metallurgy [17]. Radhika. N et.al., fabricated Al-Si12Cu/TiB2 MMC by uniform dispersion particles, which was verified by optical micrograph. Pin-on disc tribometer used to perform dry sliding wear test at room temperature. SEM micrographs confirmed severe wear and high deformation at greater loads on the HMMCs surface. Wear rate found higher as the load increased, which was confirmed by the surface

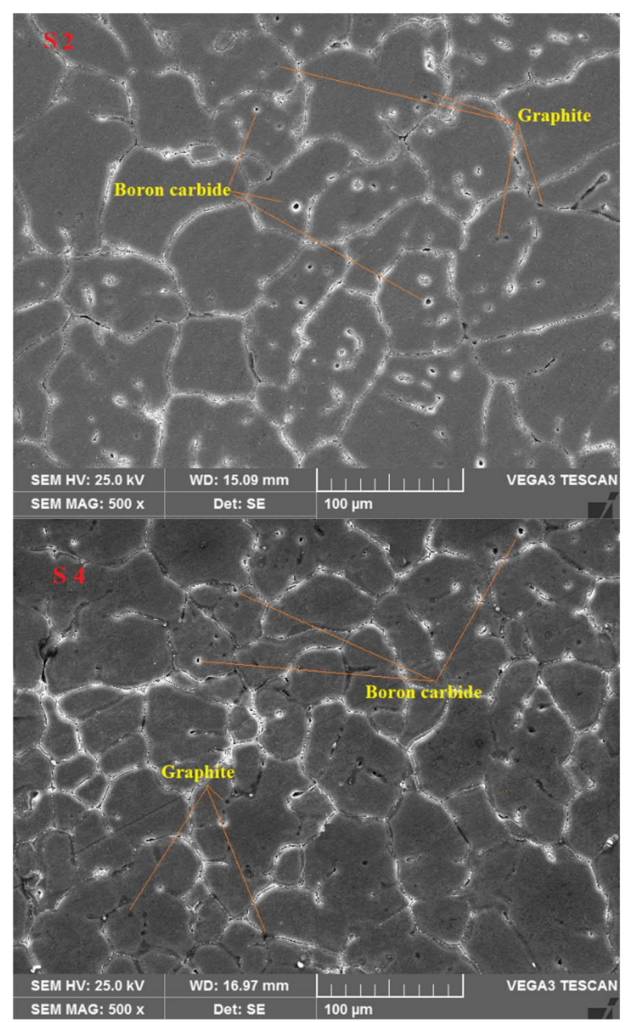



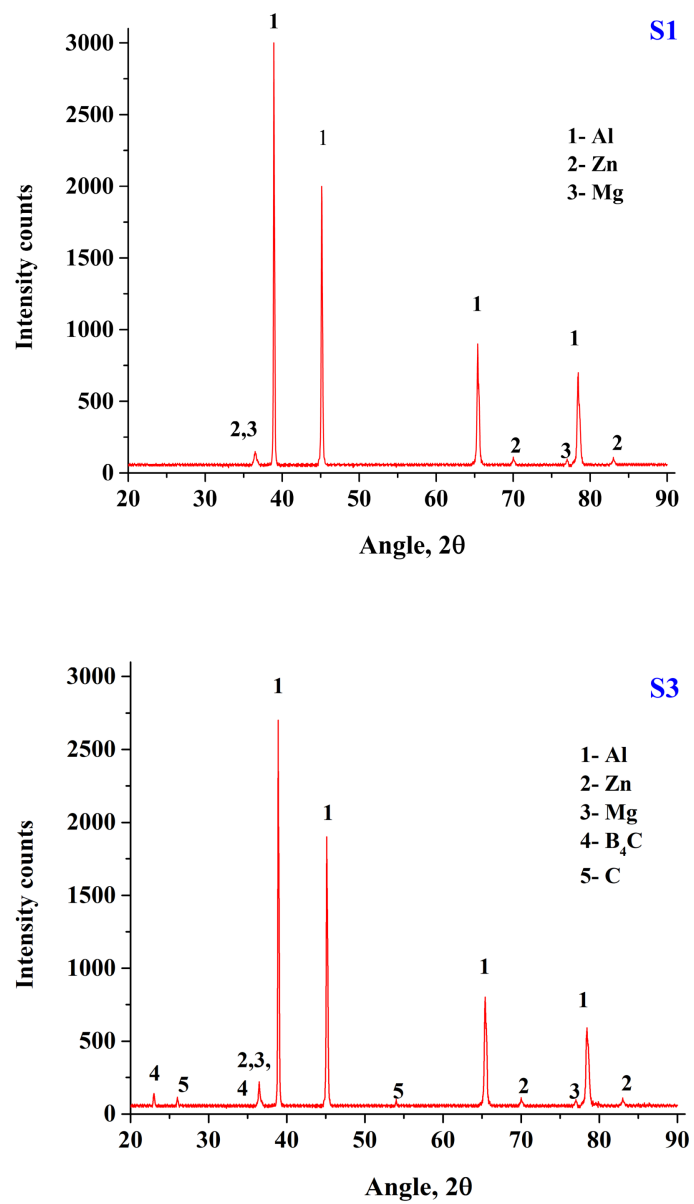

Fig. 2: XRD graphs of cast samples

plots. RSM was used for optimization of surface response and found that the optimum surface parameters for a minimum wear rate were at $10 \mathrm{~N}, 2.226 \mathrm{~m} / \mathrm{s}$, and $500 \mathrm{~m}$ [18]. Radhika. $\mathrm{N}$ et.al., evaluated the wear behavior of $\mathrm{Al}$ LM 25 with $10 \mathrm{wt} \%$ of $\mathrm{TiC}$ produced by stir casting technique were studied at different load, speed and sliding distance conditions. According to surface plots for all combinations of factors wear rate amplified with higher load and time. Which was confirmed by SEM study. The parameter was optimized by RSM study optimum results was obtained at $27 \mathrm{~N}, 139 \mathrm{rpm}$ and $3 \mathrm{~min}$ [19]. Sharma, P et.al., performed comparative study on Al6082 alloy with silicon nitride particles and Al6082 alloy with graphite particles composites produced by stir casting were experimentally tested using pin on disc tribometer. Confirmation test done for response surface model and experimental values found with minimal error. Analysis of variance carried out and most influential parameter which effect the wear was sliding distance [20-21]. Singh. G et.al., produced hybrid AA6082-T6/SiC/ $\mathrm{B}_{4} \mathrm{C}$ composites and were verified by experimental and RSA model confirmation test. Composite hardness found increased with increase of particle weight percentage $(0 \%$ to $20 \%)$. Process parameters speed, load, reinforcement and sliding distance were selected and varied at five levels and the
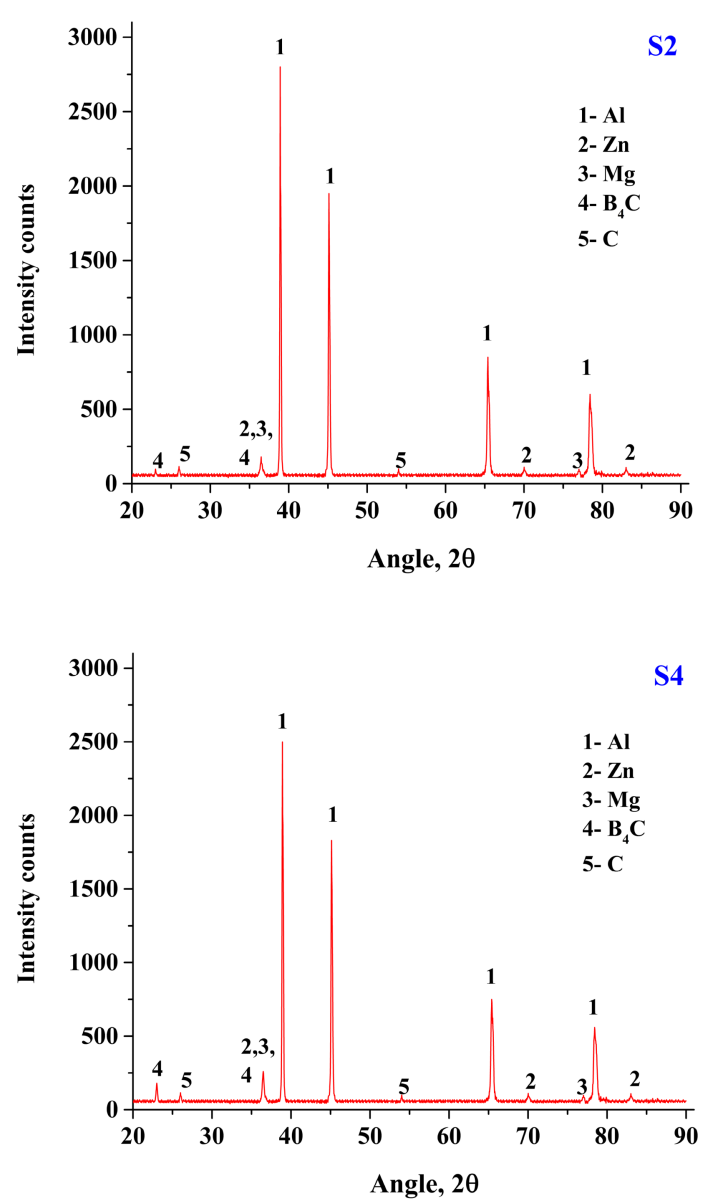

most influential parameter was found to be load followed by speed for the hybrid composite [22].

According to the literature, just a small amount of work is done on Al7029 reinforced with $\left(B_{4} C\right), G r$. There is a lack in understanding the effect of ceramic particles in Al7029 in terms of wear characteristics. Thus, Aluminium alloy (Al -7029) with boron carbide $\left(\mathrm{B}_{4} \mathrm{C}\right)$, and graphite (Gr) hybrid composite are fabricated utilizing traditional stir casting is presented in this study. The hardness and comprehensive depiction of wear under different working circumstances of base alloy with reinforcement [B4C (2\%, 4\%, 6\%) with constant $3 \% \mathrm{Gr}$ ] of the prepared composites was tested. ANOVA technique was used to discern which parameters effects on wear mechanism. Reinforced particle distribution in the matrix were found by SEM and XRD analysis.

Table 3. Process Parameters selected for Wear Test

\begin{tabular}{cccc}
\hline Level & Load (N) & Sliding speed (m/s) & Sliding distance (m) \\
\hline 1 & 15 & 1.5 & 200 \\
\hline 2 & 25 & 2.5 & 400 \\
\hline 3 & 35 & 3.5 & 600 \\
\hline
\end{tabular}




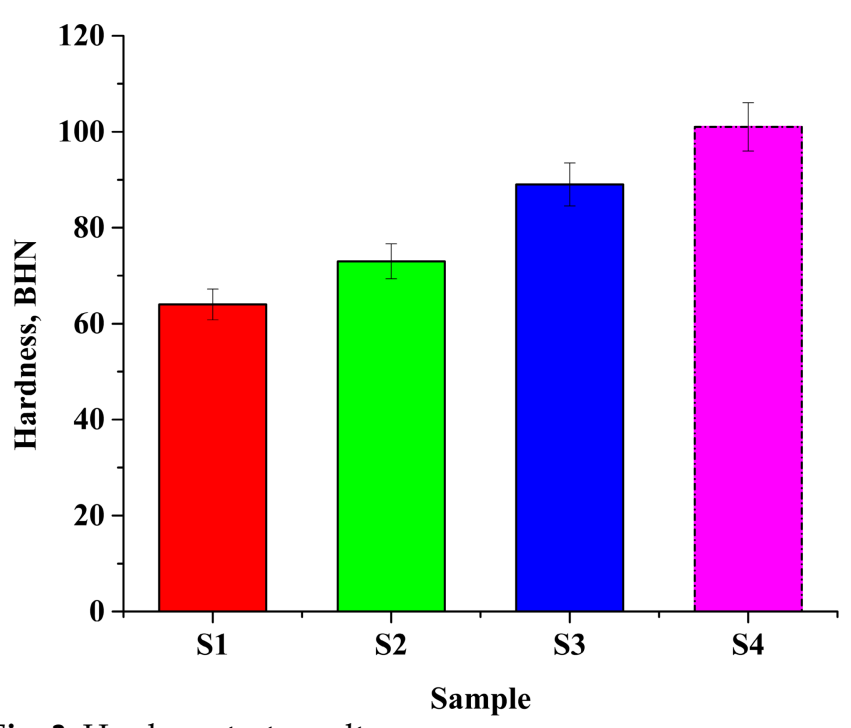

Fig. 3: Hardness test results

\section{Experimentation}

\subsection{Materials}

Aluminum-7029 alloy containing zinc (Zn) and magnesium $(\mathrm{Mg})$ was chosen as the foundation material because of its properties like, high resistance to corrosion, re-crystallization capability and cost-effectiveness. Al7029 alloy chemical composition and the material composition employed in this work are shown in Tables 1 and 2.

The composites with Al7029 matrix material were made with commercially available boron carbide (average particle size $50 \mu \mathrm{m}$ ) and graphite reinforcements (average particle size $50 \mu \mathrm{m})$.

\subsection{Casting of Composite}

Stir casting process was used to make hybrid Al7029$\mathrm{B}_{4} \mathrm{C}-\mathrm{Gr}$ composites in a $5-\mathrm{kW}$ electrical furnace. Al7029 matrix material melt was held for 90 minutes at a temperature between $600{ }^{\circ} \mathrm{C}$ and $700{ }^{\circ} \mathrm{C}$ in a graphite crucible since it does not react with matrix material. As the Al7029 ingot material reached a runny state, $\mathrm{Mg}$ (3\%) was added at molten condition of metal to allow particle dispersion within the molten metal. $2 \%$ boron carbide was preheated at $500{ }^{\circ} \mathrm{C}$ to remove any moisture or other gases. Pre-heated boron carbide fine-reinforcing particles $(50 \mu \mathrm{m})$ has been applied to a molten metal, with stirring at 150 rpm for 15-20 minutes yields a consistent distribution of $\mathrm{B}_{4} \mathrm{C}$ particulate in Al7029. Graphite (3\%) was pre-heated and poured into the premixed molten Al7029 with $\mathrm{B}_{4} \mathrm{C}$. Stirring is continued for an additional 10-15 minutes to ensure proper mixing of $\mathrm{Gr}$ with molten metal. To eliminate porosity, voids, and casting defects, the degasification agent hexa-chloroethane $\left(\mathrm{C}_{2} \mathrm{Cl}_{6}\right)$ is used. Hot metal at molten state is transferred inside the pre-heated die, progressive solidification begins. The molten metal is then allowed to solidify at room temperature before being extracted [2].

\subsection{Test method}

SEM and XRD was used to conduct the metallographic investigation of test specimen. Brinell hardness test was carried out on the test specimens prepared as per ASTM E10 standards by applying load of $240 \mathrm{kgf}$ for a period of 30 seconds. Readings were taken at five various places on the sample and an average value was used for study [8].

Dry sliding wear behavior was determined using a pinon disc testing apparatus on test specimens prepared in accordance with ASTM G99 standards, with the length and diameter of the specimen (S1, S2, S3 and S4) being $30 \mathrm{~mm}$ and $10 \mathrm{~mm}$, respectively at room temperature [2].

A $10 \mathrm{~mm}$ round pin of hybrid composite $\left(\mathrm{Al} 7029-\mathrm{B}_{4} \mathrm{C}-\right.$ Gr) was moved against a revolving steel disc (steel EN 32) at test condition. An electronic balance weigher used to find the weight loss of pin $(0.0001 \mathrm{mg}$ resolution). Disc and the test specimen were cleaned with acetone before start and at the end of experiment to avoid environmental chemical reactions. Process parameters selected for wear test are shown in Table 3.

Taguchi orthogonal array used for experimental study to find the wear rate. Using MINITAB Software (Version 19) Analysis of variance (ANOVA) under smaller the better characteristic was analyzed with experimental results to find which parameter affect the wear rate [21].

Response surface Methodology is a strategy for designing experiments in order to find the best parametric settings with the fewest number of trials possible. Using statistical tool, the impact of each input parameter on surface wear rate was investigated, which had three input parameters (load, speed, and time) and three stages of operation [22].

\section{Results and Discussions}

\subsection{Microstructure and XRD Analysis.}

SEM micrographs of base alloy and hybrid composites is shown in fig. 1. Within the Al7029, the $\mathrm{B}_{4} \mathrm{C}$ and $\mathrm{Gr}$ particles are evenly distributed, which is noticed in micrographs. The uniform particles distribution enhances the mechanical and wear properties of the reinforced Al7029. Dendritic geometrical trapping of $\mathrm{B}_{4} \mathrm{C}$ particles is observed in grain boundary regions [2]. $\mathrm{B}_{4} \mathrm{C}$ and $\mathrm{Gr}$ particles located in the grain boundaries increase the grain boundary resistance to slip. Also, both the reinforcements act as impediments to dislocations, at the boundary region which improves the wear properties.

Copper anode material used and XRD graphs of Al7029 alloy and Al7029 reinforced with $\mathrm{B}_{4} \mathrm{C}$ and $\mathrm{Gr}$ is depicted in fig. 2. Increase in peaks height at higher weight percentage of $\mathrm{B}_{4} \mathrm{C}$ is noted, according to the XRD analysis investigation. Peak $38^{\circ}, 45^{\circ}, 65^{\circ}$, and $78^{\circ} \mathrm{X}$-ray intensities indicate the existence of Auminium phase. The presence of graphite is indicated by an X-ray intensity peak of $26^{\circ}, 54^{\circ}$. $\mathrm{B}_{4} \mathrm{C}$ particles have an X-ray intensity of $23^{\circ}, 36^{\circ}$ [23-24].

\subsection{Hardness Test}

Experiments were done with the constant Gr (3\%) and 
changing weight fraction of $\mathrm{B}_{4} \mathrm{C}(2 \%, 4 \%, 6 \%)$. The graph reveals that Al7029 alloy surface hardness rises with

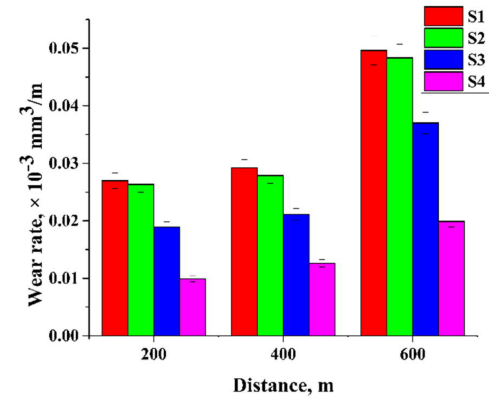

(a) At $15 \mathrm{~N}$ and $1.5 \mathrm{~m} / \mathrm{s}$

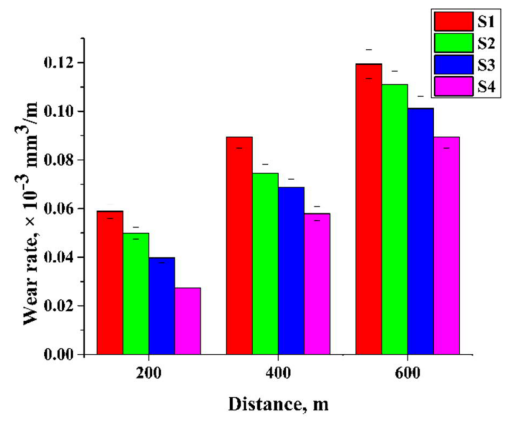

(c) At $15 \mathrm{~N}$ and $3.5 \mathrm{~m} / \mathrm{s}$

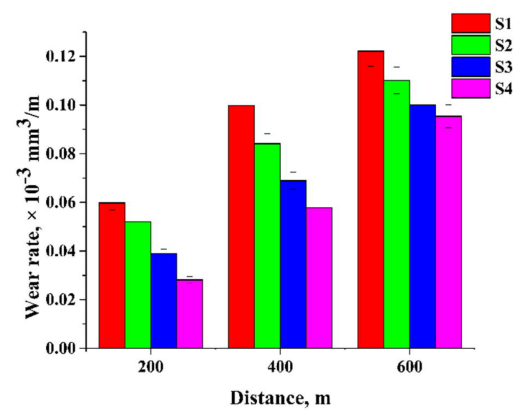

(e) At $25 \mathrm{~N}$ and $2.5 \mathrm{~m} / \mathrm{s}$

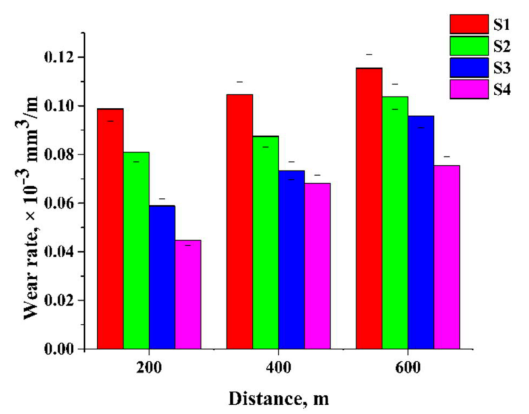

(g) At $35 \mathrm{~N}$ and $1.5 \mathrm{~m} / \mathrm{s}$ increased weight percentage of strengthening particulates $\left(\mathrm{B}_{4} \mathrm{C} \&\right.$ constant $\left.3 \% \mathrm{Gr}\right)$. The results of hardness test

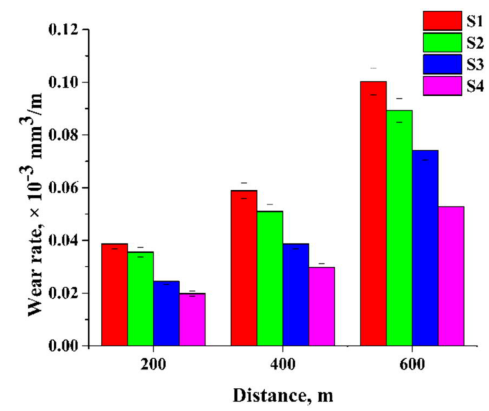

(b) At $15 \mathrm{~N}$ and $2.5 \mathrm{~m} / \mathrm{s}$

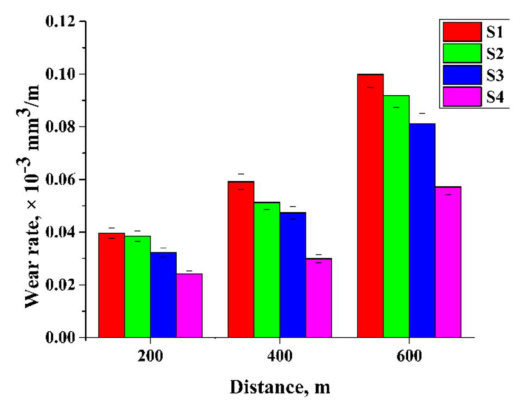

(d) At $25 \mathrm{~N}$ and $1.5 \mathrm{~m} / \mathrm{s}$

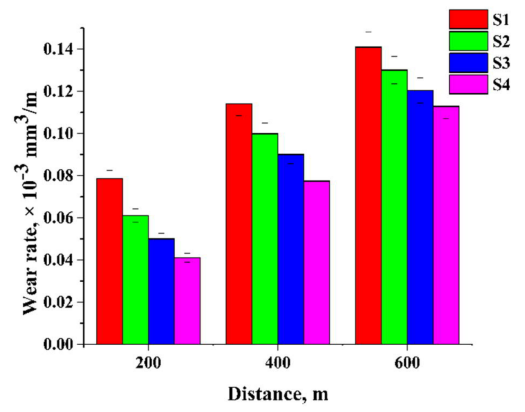

(f) At $25 \mathrm{~N}$ and $3.5 \mathrm{~m} / \mathrm{s}$

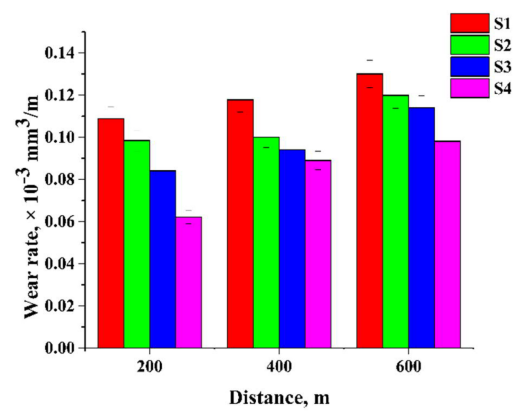

(h) At $35 \mathrm{~N}$ and $2.5 \mathrm{~m} / \mathrm{s}$

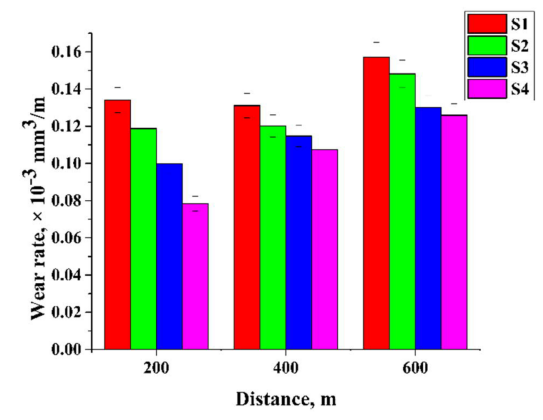

(i) At $35 \mathrm{~N}$ and $3.5 \mathrm{~m} / \mathrm{s}$ 


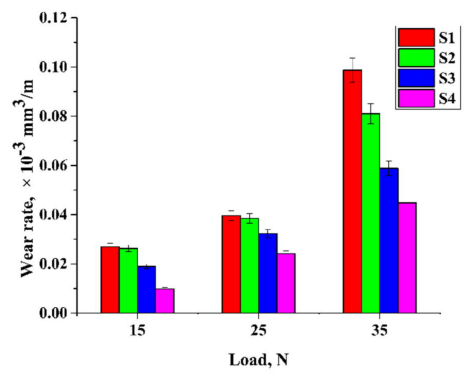

(a) At $1.5 \mathrm{~m} / \mathrm{s}$ and $200 \mathrm{~m}$

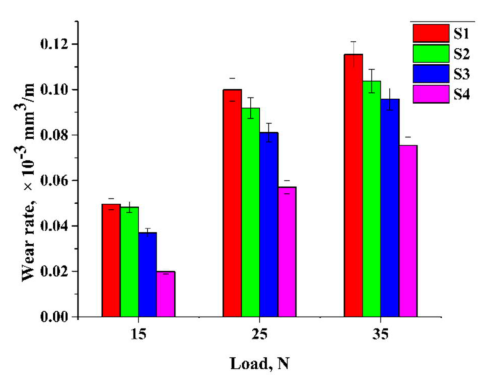

(c) At $1.5 \mathrm{~m} / \mathrm{s}$ and $600 \mathrm{~m}$

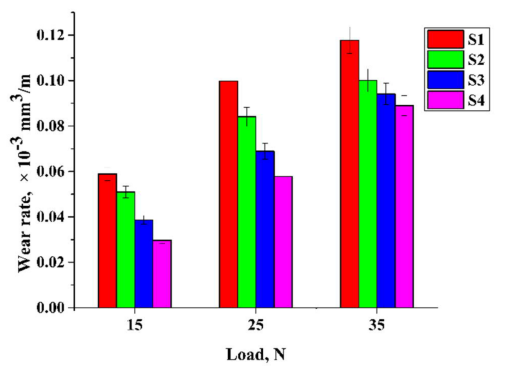

(e) At $2.5 \mathrm{~m} / \mathrm{s}$ and $400 \mathrm{~m}$

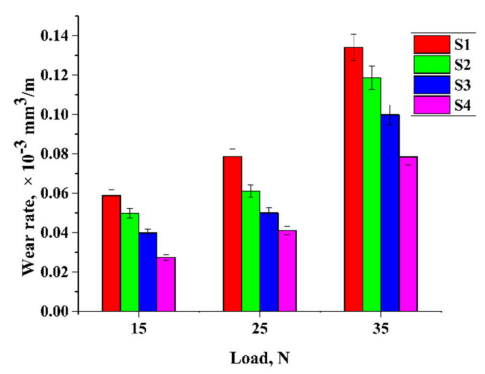

(g) At $3.5 \mathrm{~m} / \mathrm{s}$ and $200 \mathrm{~m}$

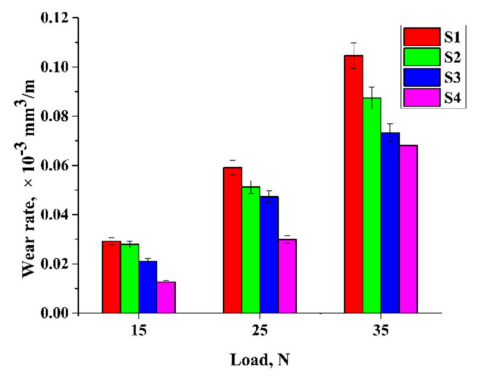

(b) At $1.5 \mathrm{~m} / \mathrm{s}$ and $400 \mathrm{~m}$

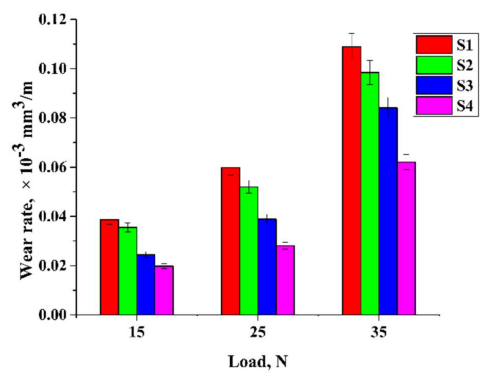

(d) At $2.5 \mathrm{~m} / \mathrm{s}$ and $200 \mathrm{~m}$

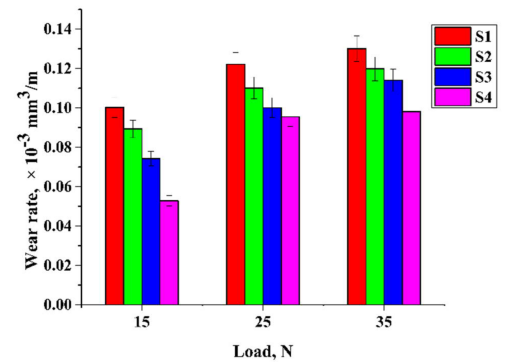

(f) At $2.5 \mathrm{~m} / \mathrm{s}$ and $600 \mathrm{~m}$

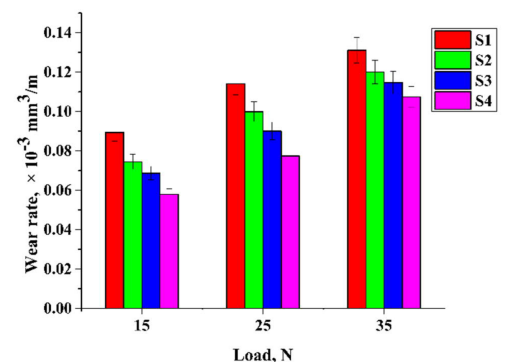

(h) At $3.5 \mathrm{~m} / \mathrm{s}$ and $400 \mathrm{~m}$

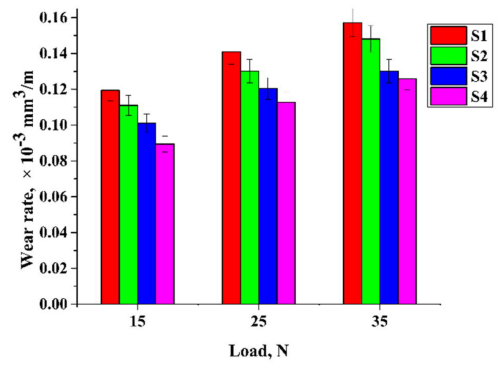

(i) At $3.5 \mathrm{~m} / \mathrm{s}$ and $600 \mathrm{~m}$

Fig. 5: Wear rate at constant load

conducted on unreinforced Al7029 and hybrid Al7029 samples have shown that matrix hardness levels are growing with reinforcement material up to $6 \% \mathrm{~B}_{4} \mathrm{C}$ (fig. 3.). Effects of hardness measurements shows that the increase 


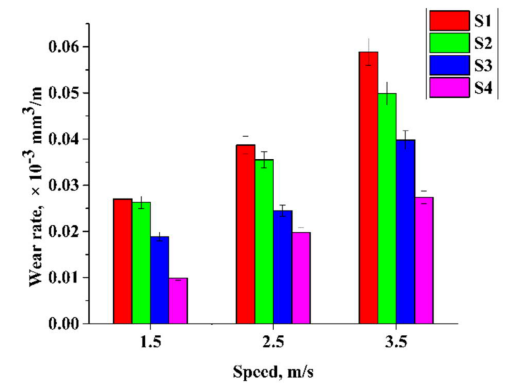

(a) At $15 \mathrm{~N}$ and $200 \mathrm{~m}$

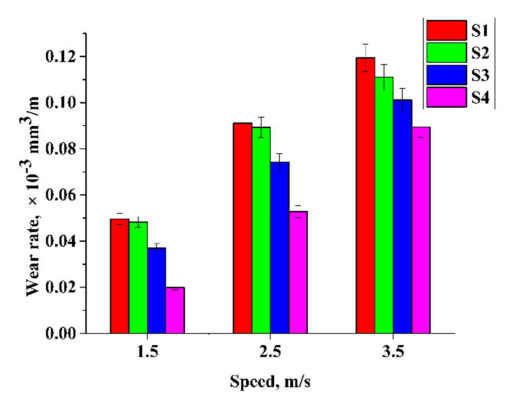

(c) At $15 \mathrm{~N}$ and $600 \mathrm{~m}$

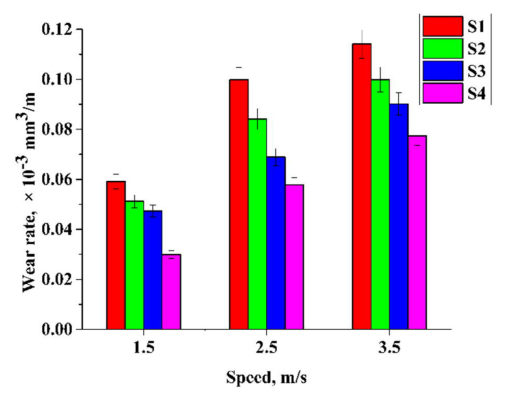

(e) At $25 \mathrm{~N}$ and $400 \mathrm{~m}$

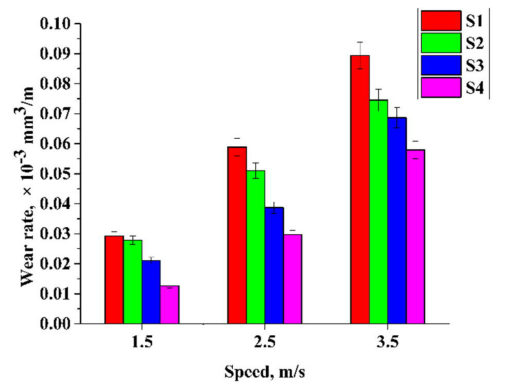

(b) At $15 \mathrm{~N}$ and $400 \mathrm{~m}$

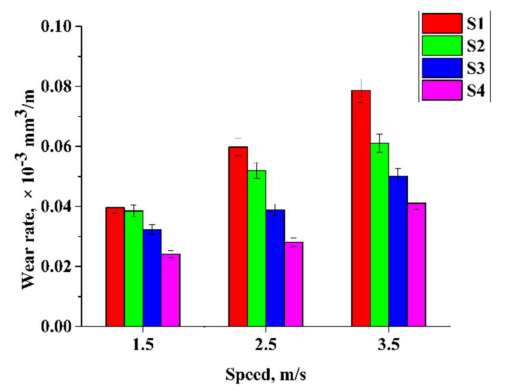

(d) At $25 \mathrm{~N}$ and $200 \mathrm{~m}$

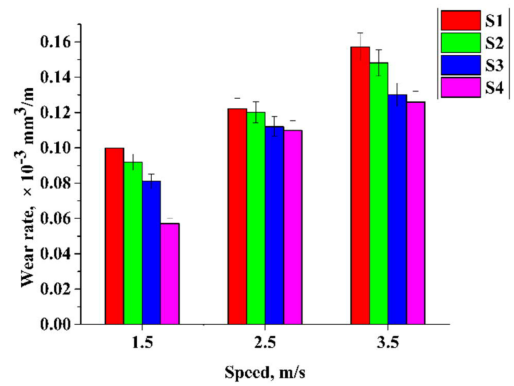

(f) At $25 \mathrm{~N}$ and $600 \mathrm{~m}$

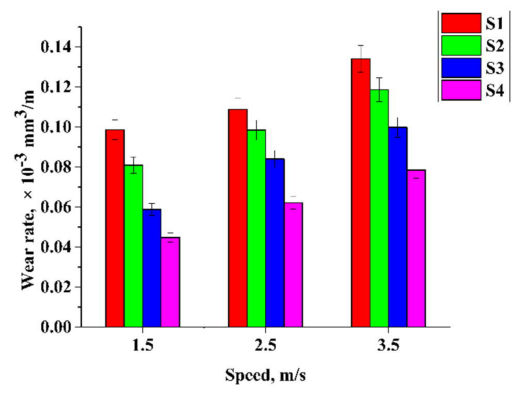

(g) At $35 \mathrm{~N}$ and $200 \mathrm{~m}$

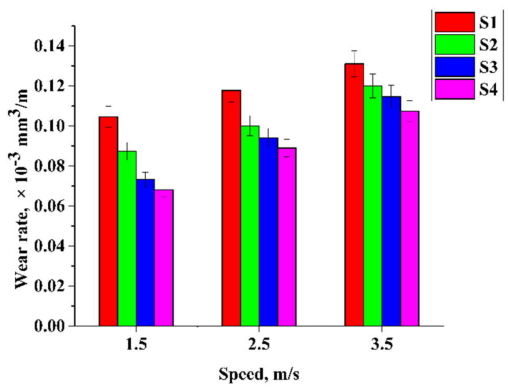

(h) At $35 \mathrm{~N}$ and $400 \mathrm{~m}$

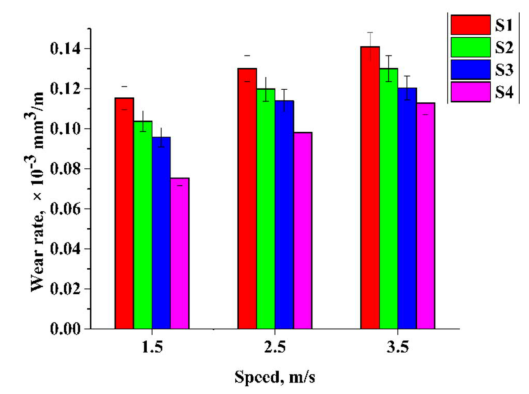

Fig. 6: Wear rate at constant sliding speed

(i) At $35 \mathrm{~N}$ and $600 \mathrm{~m}$

in reinforcement content results in a considerable increase in hardness around 38 percent compared with base alloy, which can be mainly due to; the existence of hard ceramic
$\mathrm{B}_{4} \mathrm{C} \& \mathrm{Gr}$ particles scattered in the matrix, the deformation restricted due to their inclusion during indentation and the reduced size of grain due to the chilling phase $[2,31]$. 


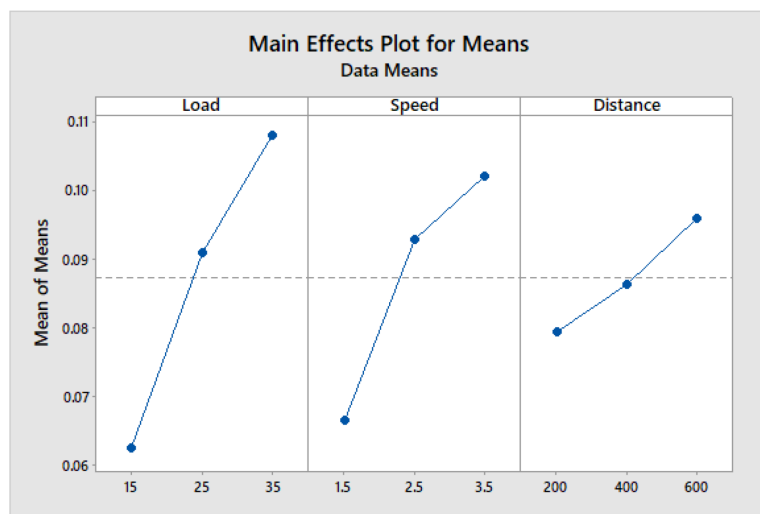

(a) Sample S1

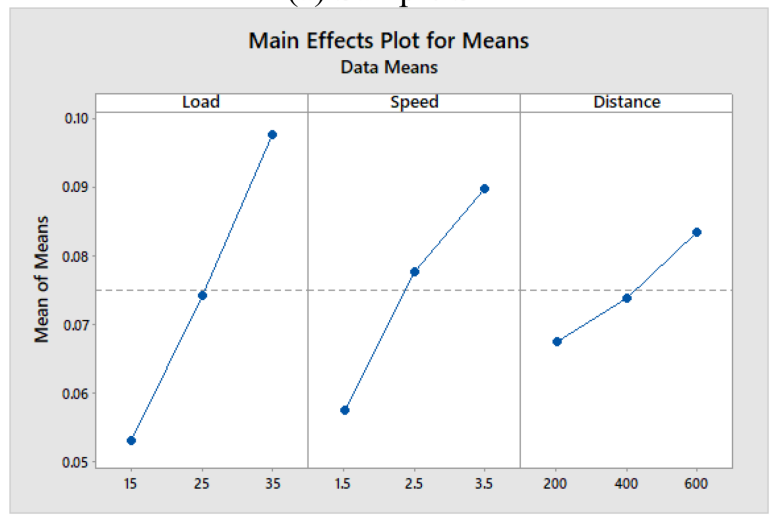

(c) Sample S3

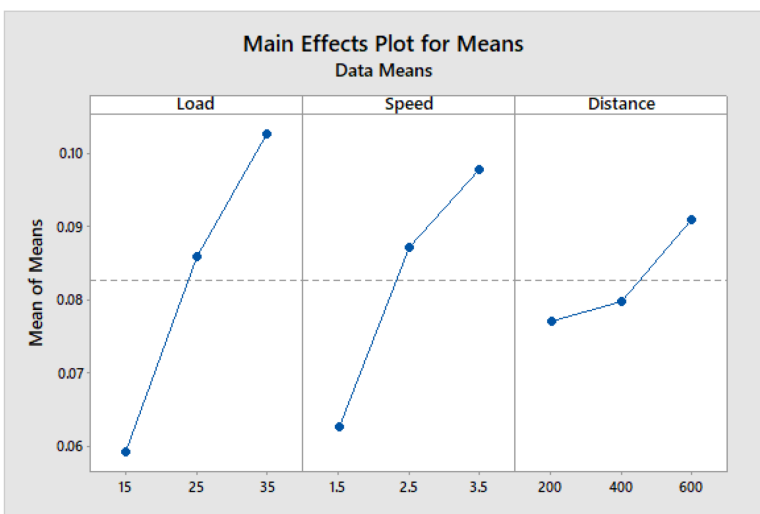

(b) Sample S2

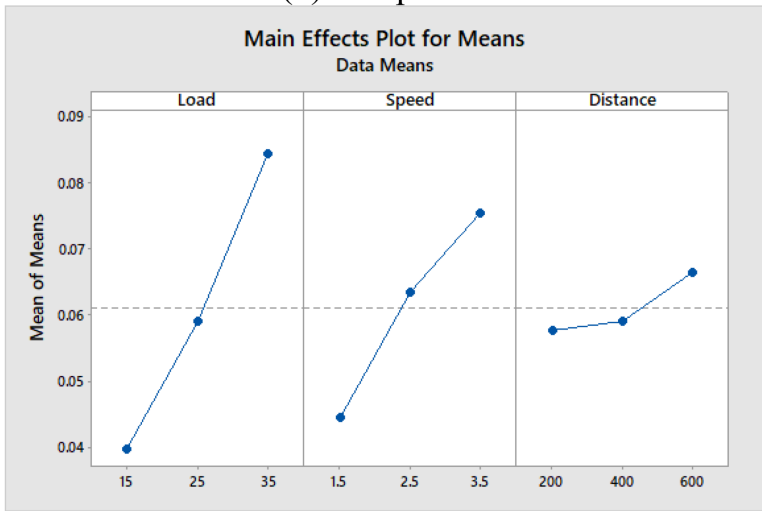

(d) Sample S4

Fig. 7: Main effect plot for Means of Al7029 and Al7029 hybrid Composites

\subsection{Dry Sliding Wear Test}

Tribological wear tests were performed on Al7029/ $\mathrm{B}_{4} \mathrm{C} / \mathrm{Gr}$ composite with varying $\mathrm{B}_{4} \mathrm{C}(2,4,6$ wt.\%) and constant $3 \mathrm{wt} . \%$ to understand the wear behavior of Gr using Pin-on-Disc wear test machine. The current study carried out using Taguchi orthogonal array with control parameters as load, sliding speed and sliding distance were used [2].

\section{i. Effect of Sliding Distance on Wear rate}

In hybrid composites, the sliding distance effect showed that as reinforcement increased, wear decreased. Wear rate is shown as a function of sliding distance for various weight fractions of hybrid metal matrix composite materials under various loads and sliding speed. Fig. 4 depicts the reducing tendency of dry sliding wear as the percent reinforcement increases. This is due to the composite's increased hardness as the percentage of reinforcement increases. The particle mixture of $\mathrm{B}_{4} \mathrm{C}$ and Gr aids to reduce wear by providing resistance to the damaging action caused by wear debris due to abrasion and self-lubricating ability of $\mathrm{Gr}[2,28]$.

The values of load and sliding speed show the wear rate increase up to $0.065 \times 10^{-3} \mathrm{~mm}^{3} / \mathrm{m}$ in average for composite, as the sliding distance increase. The smaller sliding distance coefficient value indicates that, as compared to other factors, sliding distance has a lesser influence on wear rate, where wear rate reduced around 30
-35 percent compared to base alloy as shown in fig. 4 (a-i).

\section{i. Effect of Load on Wear rate}

The pressure exerted and deformation of surfaces in contact are determined by the load. Wear rate is shown as a function of load for various weight fractions of hybrid metal matrix composite materials under various sliding distance and speed as in fig. 5. The wear sample contact stresses in the location of contact with counter surface rise as the load increases, causing more damage to surface of wear sample and causing more wear. The wear rate decreased with increased reinforcement of particle weight percentage.

Increased wear occurs at lower and higher loads up to $0.088 \times 10^{-3} \mathrm{~mm}^{3} / \mathrm{m}$ in average, due to an increase in sliding speed and distance, since the higher load raises the pressure at contact surface in rubbing action. The bigger coefficient value of loads indicates that, as compared to other factors, wear rate is influenced more by load where wear rate reduced around 18-23 percent compared to base alloy as shown in fig. $5(\mathrm{a}-\mathrm{i})$.

\section{ii. Effect of sliding speed on Wear rate}

Wear rate is shown as a function of sliding speed for various weight fractions of hybrid metal matrix composite materials under various sliding distance and load as shown in fig. 6. Considerable decrease in wear with increasing reinforcement is noted. The shear rate variation, which influences the properties of contacting surfaces, 

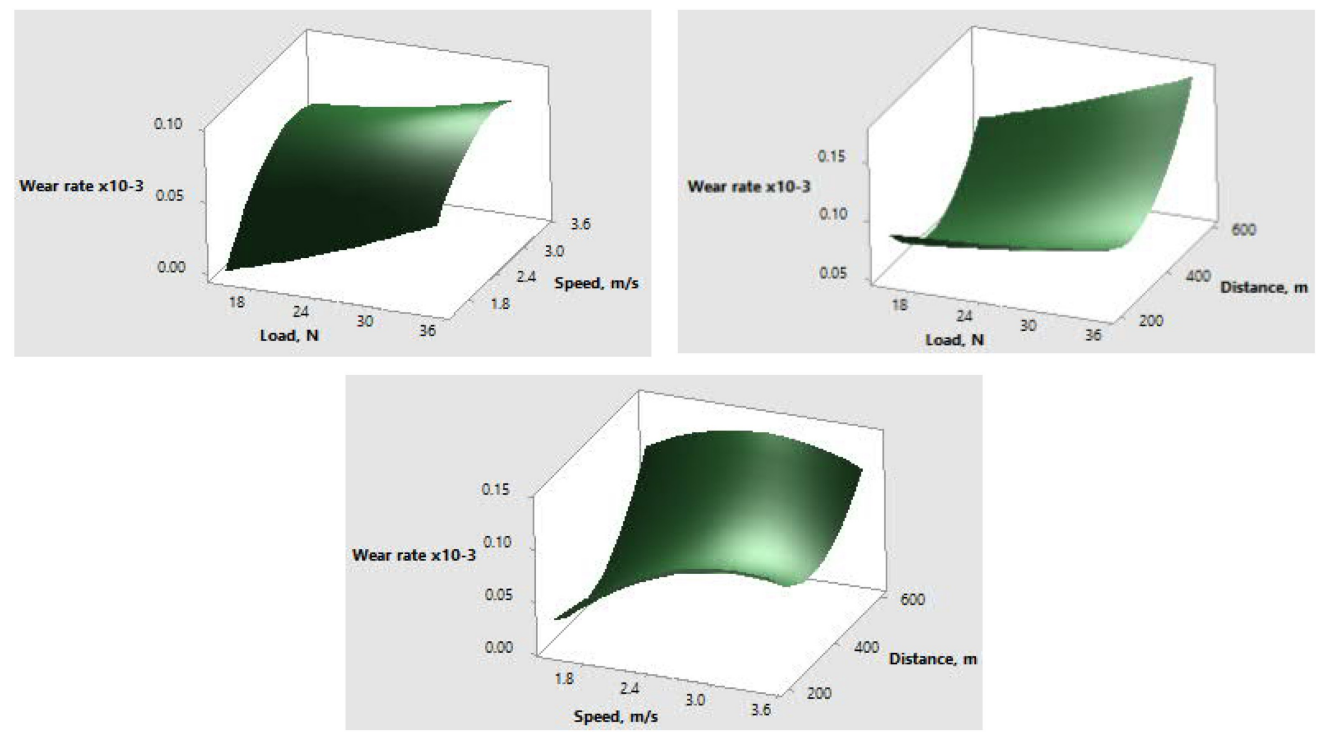

Fig. 8: Surface plot for sample S1
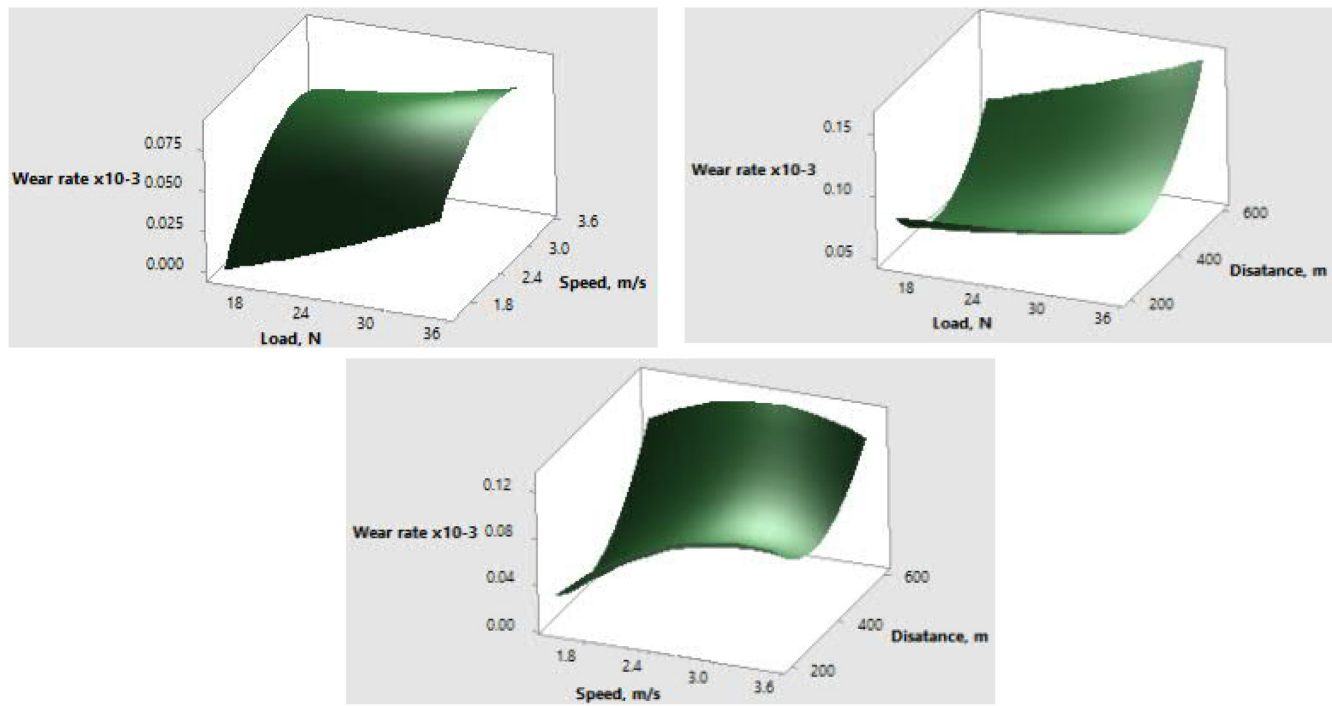

Fig. 9: Surface plot for sample S2

could be the cause of decreased wear. With higher shear strain rates, the material strength increased, resulting in a smaller contact area and, as a result, less wear with increased reinforcement. As the sliding speeds advances the surface interaction time will, which reduces wear with increased speed.

The values with sliding distance and load showed wear rate up to $0.075 \times 10^{-3} \mathrm{~mm}^{3} / \mathrm{m}$ in average for hybrid composite. The moderate coefficient value of sliding speed indicates that, as compared to other factors, sliding speed influenced with medium effect on wear rate, where wear rate reduced around $22-25$ percent compared to base alloy as shown in fig. $6(\mathrm{a}-\mathrm{i})$.

\subsection{Analysis of wear parameters}

Each process parameter's contribution percentage and significant influence were determined using Analysis of Variance (ANOVA). The ANOVA results shown in fig. 7 represents the main effect plot for means of Al7029 and Al7029 hybrid composites. Wear rate is influenced more by load and have the higher effect on wear rate of Al7029 composites and it is followed by sliding speed and sliding distance.

While running-in, the wear rate grew significantly as the sliding distance increased. Wear progressed slower with increasing sliding distance during the steady state period. Due to adhesive behavior at initial stage the wear is higher between sample and disc [20, 29]. Results shows that there is less effect on wear rate by sliding distance. Since, the increase of sliding distance, softness the surface of the composite material with lubricating nature of $\mathrm{Gr}$ which will not increase the wear rate. The wear rate results increase as shown in fig. $7(\mathrm{a}-\mathrm{d})$ as the load increases.

Unreinforced alloys also show the most wear (fig. 7a). According to the results, hybrid metal matrix composites with increased reinforcement have a lower abrasion rate. 

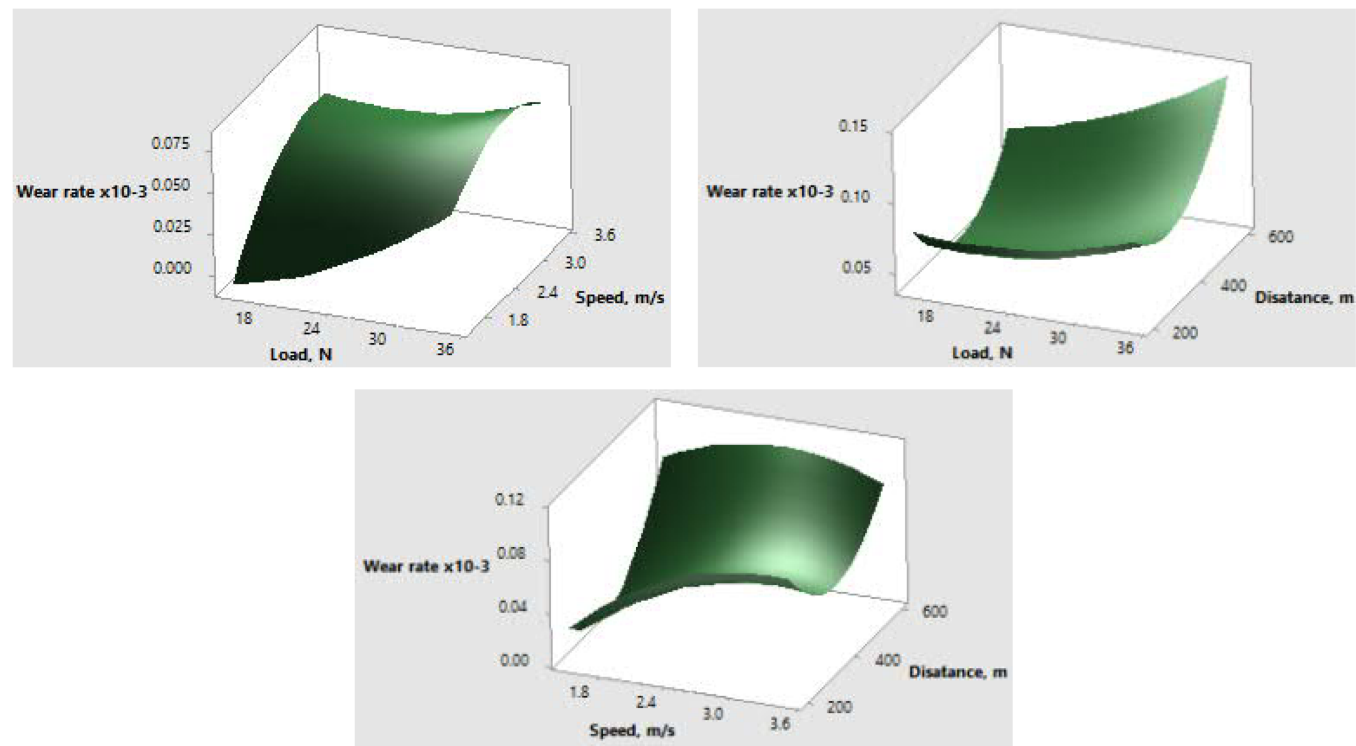

Fig. 10: Surface plot for sample S3
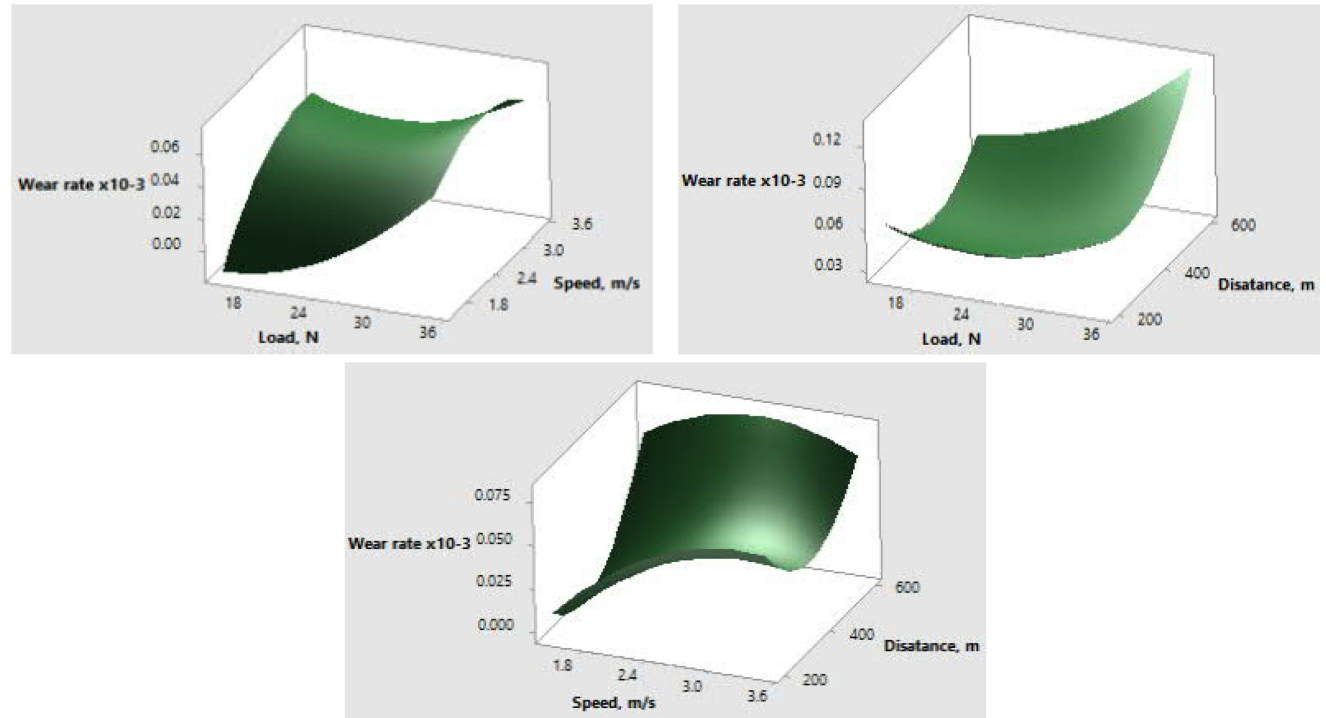

Fig. 11: Surface plot for sample S4

The particle reinforcement $\mathrm{B}_{4} \mathrm{C}$ and $\mathrm{Gr}$ has a substantial impact on the material wear rate. With increased reinforcement weight the wear rate decreased nearly by $30 \%$ compared to base alloy, which is evident from fig. 7a and $7 \mathrm{~d}$.

\subsection{RSM Analysis:}

Each pair of continuous parameters considered (i.e., load, sliding speed, and sliding distance) was used to calculate the wear rates on Al7029 and hybrid Al7029 composites. The load $25 \mathrm{~N}$, speed $2.5 \mathrm{~m} / \mathrm{s}$ and distance 400 $\mathrm{m}$ were the hold values considered. The surface plots generated aid in visualizing the relationship between the response graph and wear parameter.

During testing as the load is increased specimen in contact with rotating wheel will induce more contact pressure. Specimen wear is dependent on applied load because worn particles have ploughing and cutting properties. Hence wear rate will increase with applied load as shown in fig. $8-11$. The cutting action becomes more vigorous at greater weights, which raises the wear rate [18].

The wear rate versus sliding distance and speed on the surface plot is shown in fig. $8-11$. The wear rate is lower at low speeds and gradually increases as the speed is increased. However, at greater speeds, the wear rate appears to rise significantly. The temperature at the surfaces increases at high speeds, resulting in increased in wear rate. However, as compared to wear with respect to load, wear rates are still quite low at high speeds [19, 25]. By looking at the trends with regard to sliding distance (fig. 8 - 11), it is obvious that the rate of wear is unaffected by distance. As the sliding distance is extended, the wear rate does not increase significantly compared with speed 

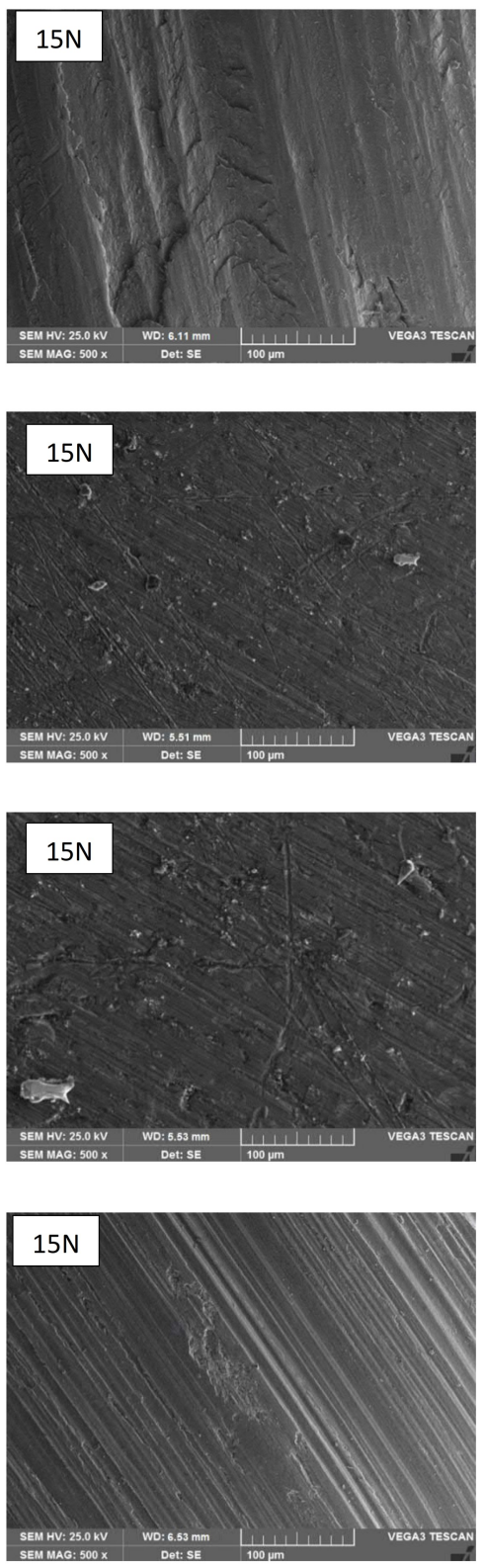

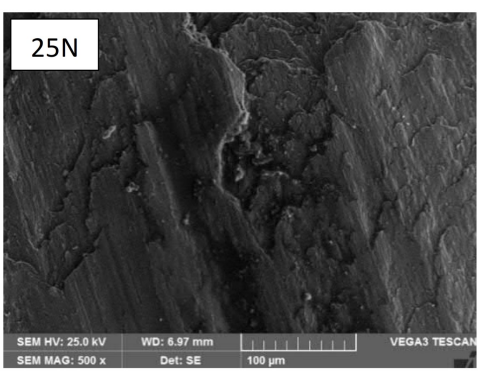

(a) for $\mathrm{Al} 7029$ (S1)

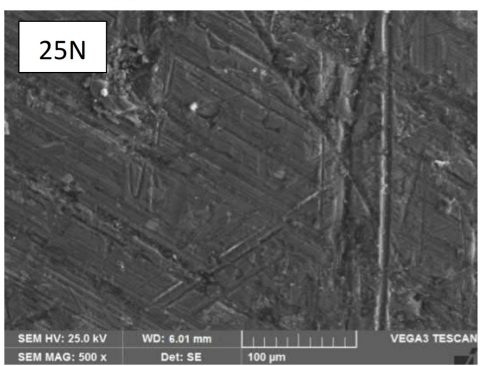

(b) for $\mathrm{A} 17029 / 2 \% \mathrm{~B}_{4} \mathrm{C} / 3 \% \mathrm{Gr}(\mathrm{S} 2)$

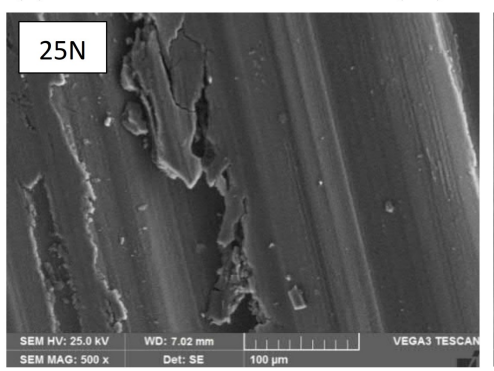

(c) for $\mathrm{A} 17029 / 4 \% \mathrm{~B}_{4} \mathrm{C} / 3 \% \mathrm{Gr}(\mathrm{S} 3)$

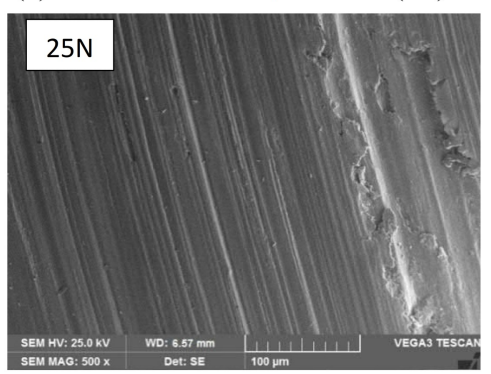

(d) for $\mathrm{Al} 7029 / 6 \% \mathrm{~B}_{4} \mathrm{C} / 3 \% \mathrm{Gr}(\mathrm{S} 4)$
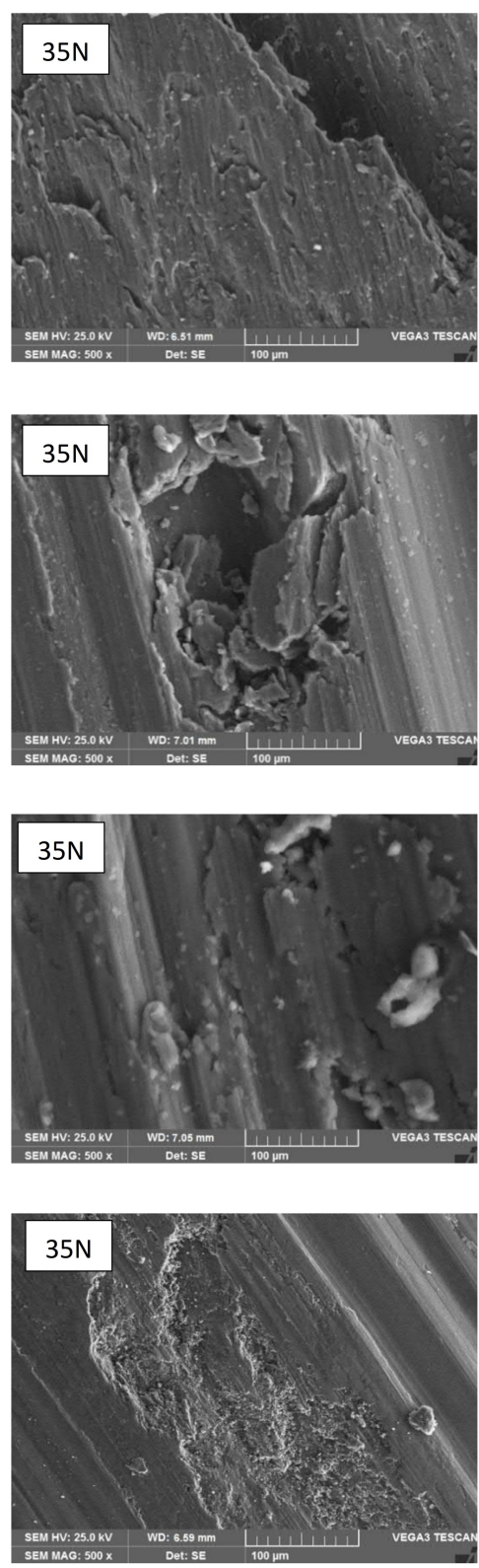

Fig. 12: SEM micrographs of worn-out surface at constant Load

and load. This demonstrates that the Al7029 hybrid composite employed in the test experiences only minor changes in wear rate as with sliding distance.

\subsection{SEM of worn-out surface}

Al7029 composite worn surfaces after the dry sliding test at different process parameter $15 \mathrm{~N}, 25 \mathrm{~N}$ and $35 \mathrm{~N}$ (load) and $1.5 \mathrm{~m} / \mathrm{s}, 2.5 \mathrm{~m} / \mathrm{s}$ and $3.5 \mathrm{~m} / \mathrm{s}$ (sliding speed) and $200 \mathrm{~m}, 400 \mathrm{~m}$ and $600 \mathrm{~m}$ (sliding distance) have been studied under a SEM. The SEM micrographs are considered for the most influencing parameter for wear, which is to be load as confirmed by experimental, ANOVA and RSM result. Fine scratches and shallow grooves can be seen on the surface abraded at $15 \mathrm{~N}$ as shown in fig. 12 (ad) and material loss is minimal for $\mathrm{Al} 7029 / 6 \% \mathrm{~B}_{4} \mathrm{C} / 3 \% \mathrm{Gr}$ hybrid composite.

Surface delamination observed was very much higher as the load is increased to $25 \mathrm{~N}$ as shown in fig. 12 (a-d). During this loading state, the abrasive medium of worn surface undergoes crushing, which increases material removal. With an increased load of $35 \mathrm{~N}$, the worn surface of the specimen shows deeper grooves. The worn surface particles are crushed between the rotating wheel and the specimen leading to deeper penetration, pitting, and grooving. As a result of this rate of material removal at the higher loading condition, is very much higher, hence the surface is severely delaminated. Due to increased abrasion induced by the implanted particles material loss from the specimen rises.

Overall Al7029 show higher wear rate with increased 
load about $0.15 \times 10^{-3} \mathrm{~mm}^{3} / \mathrm{m}$ and $\mathrm{Al} 7029 / 6 \% \mathrm{~B}_{4} \mathrm{C} / 3 \% \mathrm{Gr}$ show the least around $0.11 \times 10^{-3} \mathrm{~mm}^{3} / \mathrm{m}$. The increase in reinforcement percentage of $\mathrm{B}_{4} \mathrm{C}$ to Al7029 alloy reduces wear rate and 3\% Gr present act as a solid lubricant [26-30].

\section{Conclusions}

Stir casting was used to make Al7029 alloy and Al7029/ $\mathrm{B}_{4} \mathrm{C} / \mathrm{Gr}$ HMMCs and the study concludes with the following remarks

- $\mathrm{B}_{4} \mathrm{C}$ and $\mathrm{Gr}$ were found to be distributed reliably and was confirmed from SEM and XRD, the interfacial analysis indicated that the reinforcement particulate is related closely to the matrix strengthening.

- Brinell hardness of hybrid Al7029/6\% $\mathrm{B}_{4} \mathrm{C} / 3 \% \mathrm{Gr}$ composite is higher due to the increased reinforcement of ceramic particle.

- The wear rates were found against the process parameters after the specimens were exposed to a dry sliding wear test. Wear rate found augmented with change in process parameter and reduced with reinforcement weight percentage increased.

- Effect of wear rate found highest with change in load, average with change in sliding speed and lowest with change in sliding distance.

- Mean effect plot of ANOVA result confirmed load as the major influencing factor with respect to wear rate followed by sliding speed.

- Response surface plot and mean effect plot of ANOVA correlates with experimental result and concludes wear rate influenced by change in load.

- It's revealed by SEM analysis of the worn specimens that when the load increased, the rate at which material was removed also increased, in turn increasing the wear rate.

\section{References}

[1] Davis, J. R. (Ed.). (1999). Corrosion of Aluminum and Aluminum Alloys. https://doi.org/10.31399/ asm.tb.caaa.9781627082990

[2] Sharath, B.N., Madhu, K.S. and Venkatesh, C.V., 2019. Experimental Study on Dry sliding Wear Behaviour of Al-B4C-Gr Metal Matrix Composite at Different Temperatures. J. Applied Mechanics and Materials, 895, pp. 96-101.

[3] Manjunatha, B., Niranjan, H. B., \& Satyanarayana, K. G. (2018, June). Effect of amount of boron carbide on wear loss of Al-6061 matrix composite by Taguchi technique and Response surface analysis. In IOP Conference Series: Materials Science and Engineering (Vol. 376, No. 1, p. 012071). IOP Publishing. https://doi.org/10.1088/1757899X/376/1/012071

[4] Soy, U., Ficici, F., \& Demir, A. (2012). Evaluation of the Taguchi method for wear behavior of $\mathrm{Al} / \mathrm{SiC} / \mathrm{B} 4 \mathrm{C}$ composites. Journal of Composite Materials, 46(7), 851-859. https://doi.org/10.1177/0021998311410510
[5] Muthazhagan, C., Gnanavelbabu, A., Bhaskar, G. B., \& Rajkumar, K. (2014). Influence of graphite reinforcement on mechanical properties of aluminum-boron carbide composites. In Advanced Materials Research (Vol. 845, pp. 398-402). Trans Tech Publications Ltd. https://doi.org/10.4028/ www.scientific.net/AMR.845.398

[6] Singh, G., \& Goyal, S. (2018). Dry sliding wear behaviour of AA6082-T6/SiC/B4C hybrid metal matrix composites using response surface methodology. Proceedings of the Institution of Mechanical Engineers, Part L: Journal of Materials: Design and Applications, 232(11), 952-964. https:/ / doi.org/10.1177/1464420716657114

[7] Kumar, A., \& Kumar, M. (2020). Mechanical and dry sliding wear behaviour of B4C and rice husk ash reinfroced Al 7075 alloy hybrid composite for armors application by using taguchi techniques. Materials Today: Proceedings, 27, 2617-2625. https:// doi.org/10.1016/j.matpr.2019.11.075

[8] Sharath, B. N., Venkatesh, C. V., Afzal, A., Baig, M. A. A., \& Kumar, A. P. (2021). Study on effect of ceramics on dry sliding wear behaviour of Al-Cu-Mg based metal matrix composite at different temperature. Materials Today: Proceedings. https:/ / doi.org/10.1016/j.matpr.2021.04.034

[9] Baradeswaran, A., Elayaperumal, A., \& Issac, R. F. (2013). A statistical analysis of optimization of wear behaviour of Al-Al2O3 composites using Taguchi technique. Procedia Engineering, 64, 973-982. https:/ / doi.org/10.1016/j.proeng.2013.09.174

[10] Yao, Y. T., Jiang, L., Fu, G. F., \& Chen, L. Q. (2015). Wear behavior and mechanism of B4C reinforced $\mathrm{Mg}$ -matrix composites fabricated by metal-assisted pressure less infiltration technique. Transactions of Nonferrous Metals Society of China, 25(8), 25432548 .

[11] Baradeswaran, A., Vettivel, S. C., Perumal, A. E., Selvakumar, N., \& Issac, R. F. (2014). Experimental investigation on mechanical behaviour, modelling and optimization of wear parameters of B4C and graphite reinforced aluminium hybrid composites. Materials \& Design, 63, 620-632.

[12] Suresha, S., \& Sridhara, B. K. (2012). Friction characteristics of aluminium silicon carbide graphite hybrid composites. Materials \& Design, 34, 576-583. https:/ / doi.org/10.1016/j.matdes.2011.05.010

[13] Imran, M., Khan, A. A., Megeri, S., \& Sadik, S. (2016). Study of hardness and tensile strength of Aluminium-7075 percentage varying reinforced with graphite and bagasse-ash composites. ResourceEfficient Technologies, 2(2), 81-88. https:// doi.org/10.1016/j.reffit.2016.06.007

[14] Baradeswaran, A. E. P. A., \& Perumal, A. E. (2013). 
Influence of $\mathrm{B} 4 \mathrm{C}$ on the tribological and mechanical properties of $\mathrm{Al}$ 7075-B4C composites. Composites Part B: Engineering, 54, 146-152. https:/ / doi.org/10.1016/j.compositesb.2013.05.012

[15] Balaji, S., Maniarasan, P., Alagarsamy, S. V., \& Raveendran, P. (2021). Dry sliding wear behaviour of aluminium metal matrix composite using response surface methodology. Materials Today: Proceedings. https:/ / doi.org/10.1016/j.matpr.2021.03.429

[16] Kumar, R., \& Dhiman, S. (2013). A study of sliding wear behaviors of Al-7075 alloy and Al-7075 hybrid composite by response surface methodology analysis. Materials \& Design, 50, 351-359. https:/ / doi.org/10.1016/j.matdes.2013.02.038

[17] Rajesh, S., Rajakarunakaran, S., \& Pandian, R. S. (2012). Modeling and optimization of sliding specific wear and coefficient of friction of aluminum based red mud metal matrix composite using taguchi method and response surface methodology. Materials physics and Mechanics, 15(2), 150-166.

[18] Radhika, N., \& Raghu, R. (2015). Dry sliding wear behaviour of aluminium Al-Si12Cu/TiB2 metal matrix composite using response surface methodology. Tribology Letters, 59(1), 1-9. https:/ / doi.org/10.1007/s11249-015-0516-3

[19] Radhika, N., \& Charan, K. S. (2017). Experimental analysis on three body abrasive wear behaviour of stir cast Al LM 25/ TiC metal matrix composite. Transactions of the Indian Institute of Metals, 70(9), 2233-2240. https:/ / doi.org/10.1007/s12666-017-1061 $-6$

[20] Sharma, P., Khanduja, D., \& Sharma, S. (2015). Parametric study of dry sliding wear of aluminium metal matrix composites by response surface methodology. Materials Today: Proceedings, 2(4-5), 2687-2697. https:/ / doi.org/10.1016/ j.matpr.2015.07.234

[21] Sharma, P., Khanduja, D., \& Sharma, S. (2016). Dry sliding wear investigation of Al6082/Gr metal matrix composites by response surface methodology. Journal of Materials Research and Technology, 5(1), 29-36. https://doi.org/10.1016/j.jmrt.2015.05.001

[22] Singh, G., \& Goyal, S. (2018). Dry sliding wear behaviour of AA6082-T6/SiC/B4C hybrid metal matrix composites using response surface methodology. Proceedings of the Institution of Mechanical Engineers, Part L: Journal of Materials: Design and Applications, 232(11), 952-964.

[23] Şimşek, İ. (2019). The effect of B4C amount on wear behaviors of Al-Graphite/B4C hybrid composites produced by mechanical alloying. Journal of Boron, 4(2), 100-106. https:/ / doi.org/10.30728/ boron. 556707
[24] Lyu, X., Zhao, Z., Sun, H., Jiang, X., Hu, C., Song, T., \& Luo, Z. (2020). Influence of Y2O3 contents on sintering and mechanical properties of $\mathrm{B} 4 \mathrm{C}-\mathrm{Al} 2 \mathrm{O} 3$ multiphase ceramic composites. Journal of Materials Research and Technology, 9(5), 11687-11701. https:// doi.org/10.1016/j.jmrt.2020.08.072

[25] Sharath, B. N., Venkatesh, C. V., Afzal, A., Aslfattahi, N., Aabid, A., Baig, M., \& Saleh, B. (2021). Multi Ceramic Particles Inclusion in the Aluminium Matrix and Wear Characterization through Experimental and Response Surface-Artificial Neural Networks. Materials, 14(11), 2895. https:// doi.org/10.3390/ ma14112895

[26] Sharath, B. N., Jeevan, T. P., Baig, M. A. A., Ashrith, H. S., Afzal, A., \& Reddy, A. R.

(2021). Machinability studies on boron carbide and graphite reinforced aluminium hybrid composites. Materials Today: Proceedings.

[27] Sharath, B. N., \& Venkatesh, C. V. (2021). Study On Effect of Boron Carbide, Aluminium Oxide and Graphite on Dry Sliding Wear Behaviour of Aluminium Based Metal Matrix Composite at Different Temperature. Tribologia-Finnish Journal of Tribology, 38(1- 2), 35-46. https:/ / doi.org/10.30678/ fjt.99931

[28] Pradeep, D. G., Sharath, B. N., Afzal, A., Baig, M. A. A., \& Shanmugasundaram, M. (2021). Study on scratch behavior of $\mathrm{Ni}-\mathrm{A} 12 \mathrm{O} 3$ coating composition on Al-2219 substrate by electro deposited technique. Materials Today: Proceedings. https:// doi.org/10.1016/j.matpr.2021.04.033

[29] Chikkegouda, S. P., Gurudath, B., Sharath, B. N., Karthik, S., \& Mahale, R. S. (2021). Mechanical and Tribological Characteristics of Aluminium 2618 Matrix Composite Reinforced with Boron Carbide. Biointerface Research in Applied Chemistry Vol. 12, 4, 2022, 4544 - 4556.

[30] Sharath, B. N., Madhu, K. S., Pradeep, D. G., \& Venkatesh, C. V. (2021, October). Tribological Suitability of aluminium hybrid composite above atmospheric temperature. In IOP Conference Series: Materials Science and Engineering (Vol. 1189, No. 1, p. 012018). https://doi.org/10.1088/1757899X/1189/1/012018

[31] Madhu, K. S., Sharath, B. N., Venkatesh, C. V., \& Pradeep, D. G. (2021, October). Evaluation of Mechanical Properties of Ceramic Reinforced Aluminium-7029 Hybrid Composite. In IOP Conference Series: Materials Science and Engineering (Vol. 1189, No. 1, p. 012019). https:/ / doi.org/10.1088/1757-899X/1189/1/012019 